not write about it unless he did so. Czerkas agreed to this, says Sloan.

Meanwhile, Czerkas was working on a paper about the fossil that he hoped to publish in a major journal. Last summer, the plan was to publish the manuscript naming the specimen, with the National Geographic article following on its heels.

Although he does not hold a university degree, Czerkas says that he is widely respected in the scientific community for helping major museums create dinosaur displays. These contacts led him to his collaborators: Philip Currie, a palaeontologist at the Royal Tyrrell Museum of Palaeontology in Canada who has close links to China; Xu, who Currie recruited to the project; and palaeontologist Timothy Rowe, who has a laboratory at the University of Texas that scans specimens.

According to Rowe, by early August his laboratory had found problems with the fossil - in particular the added tail and questions relating to reconstructed leg bones. Rowe described the problems to Czerkas and Currie at a meeting in his laboratory.

Currie was in Argentina and unavailable for comment last week, but has been quoted in newspaper articles as saying that the whole affair is deeply embarrassing.

Czerkas finally agreed to modify the manuscript to address concerns, says Rowe, and the paper was sent to Nature, where it was rejected. With National Geographic's September printing deadline approaching, Czerkas sent the manuscript to Science, which sent it out for peer review. Two reviewers rejected it in the first week of September.

Suggesting the possibility that "the specimen was smuggled out of China and illegally purchased", one reviewer suggested that the specimen had been "doctored" by its unknown collectors "to enhance its value". He or she also commented that the specimen should be returned to China before being considered for publication.

Czerkas, the lead author, never fully informed National Geographic about the details of those rejections, says Sloan. National Geographiclearnt of Science's rejection shortly after its deadline for the November issue.

In October, National Geographic held a news conference to highlight its November issue, unveil the fossil and announce that its repatriation to China had been agreed.

But according to $\mathrm{Xu}$, Czerkas wanted the fossil to stay in the Utah museum for up to five years before sending it back. He says that Czerkas also sought potentially valuable casts of other Chinese dinosaurs and scientific exchanges in return for the fossil.

$\mathrm{Xu}$ says that he has since been negotiating with Czerkas to get the fossil returned immediately, as his superiors desire. He and Sloan say that last month, after newspaper reports had questioned the fossil's authenticity, Czerkas dropped the display demands.
Rowe withdrew from the project in early January, upset that Czerkas hadn't told National Geographic earlier about the fossil's composite nature and other issues.

Last week, Slade flew to Washington, picked up the fossil at the National Geographic and returned it to Utah. He says that the fossil is undergoing further studies and that an attempt will be made to publish the findings in another journal. He added that the patrons - who he declined to identify - have yet to transfer ownership of the fossil to the Blanding museum.

Xu may bring a similar fossil to Washington for independent comparison with Czerkas's specimen. Czerkas may then report the findings to a palaeontology meeting in March at the Graves Museum in Florida.

Czerkas says that he will return the fossil to China this spring, possibly at the June meeting of the International Society of Avian Paleontology in Beijing.

\title{
The biggest, wildest fossil market in the west
}

\section{Tucson, Arizona}

The Gem, Mineral and Fossil Showcase of Tucson, a city-wide street fair of international artefacts, is a major marketplace for fossils, many of which, some claim, have been smuggled out of China and other countries.

Chinese bird fossils from the early Cretaceous that have yet to be described, ancient skulls of rhino and ivory-tusked elephant, and dinosaur eggs were all on sale at the annual two-week event that ended last week.

Some of the dealers selling Chinese fossils say they have documents showing they were legally exported. But US and Chinese scientists say the papers are irrelevant, as the specimens are Chinese cultural treasures.

US customs officials say that the importation, possession and sale of a smuggled specimen may violate various federal laws. But an in-depth legal analysis of each case is needed to determine if a criminal offense was committed, says Customs Special Agent Lisa Fairchild in Washington DC.

About 3,000 dealers mostly selling gems and minerals - sell their wares in hotel rooms, on patches of ground and in huge tents. Dinosaur eggs and rhino skulls could be found among some of the 24 individually operated shows in Tucson, but this year most of the questionable Chinese fossils were being

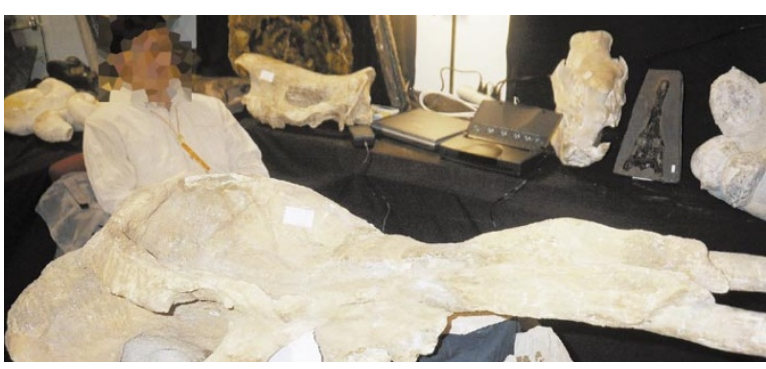

Happy hunting ground: A fossil elephant skull, for sale in Tucson.

sold at a show held in a converted hotel.

Chinese fossils large and small were displayed throughout the hotel. One room contained boxes of dozens of dinosaur eggs stacked like eggs in a supermarket.

It was in this setting that that dinosaur enthusiast Stephen Czerkas organized the purchase last year of the controversial bird fossil that found its way into the National Geographic magazine last November (see main story).

Czerkas refuses to say who sold the fossil for $\$ 80,000$. He says that, after he had found it, a patron went to Tucson to buy the fossil for the small Dinosaur Museum in Blanding, Utah. But the museum's main patron, Dale Slade, says that Czerkas went to Tucson and bought the fossil himself.

Timothy Rowe, a

University of Texas palaeontologist who has analysed the fossil, visited Tucson this year to investigate its source. While there he met dealers such as Zhouping Guo, a watercompany geologist who runs the company Sin-Am Bridge out of his home near San Diego, California.

Rowe says that Zhouping knows Czerkas and that during Rowe's visit he produced three Chinese bird fossils that appeared to be species not yet described in the scientific literature.

Zhouping denies selling Czerkas the fossil. He says that he has documents from a Chinese museum proving his specimens were legally exported for scientific exchange, although he refused Nature's request to inspect the documents.

Martin Zinn, who ran the show that included independent firms like Sin-Am Bridge, says he prohibits dealers from selling smuggled or illegal goods, that Sin-Am insisted its specimens were properly documented, and that all was "normal".

A spokeswoman for the Metropolitan Tucson Convention and Visitors Bureau, which organizes the showcase, says the organization knew nothing of illegal sales and was not responsible for independent dealers. 